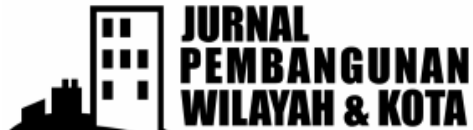

\section{Pengaruh Rehabilitasi Saluran Induk Kalibawang terhadap Pengembangan Ekonomi Wilayah Kecamatan Kalibawang Kabupaten Kulon Progo}

\author{
Muhamat Andika1, Brotosunaryo²
}

Diterima : 24 Juli 2013

Disetujui : 19 Agustus 2013

\begin{abstract}
One of the irrigation infrastructure developments realized by the government is Kalibawang Irrigation Canal in Kulon Progo regency. The rehabilitation of Kalibawang Primary Canal in 2010 and 2011 is expected to be beneficial for the society's corps. This study aims at describe the effect of the rehabilitation of Kalibawang Primary Canal towards the economy development of Kalibawang Subdistrict by considering the extensification of agriculture, the intensification of agriculture, the rice production, the agricultural activity in upstream and downstream, and the pattern and structure of the space. This study is quantitative research which is supported by the descriptive analysis as well as superimposes spatial analysis technique. The findings of this study conclude that the rehabilitation of Kalibawang Primary Canal gives positive effect upon the economy development in Kalibawang Subdistrict of Kulon Progo Regency.
\end{abstract}

Key words: rehabilitation, irrigation, kalibawang, regional development

\section{ABSTRAK}

Pembangunan infrastruktur irigasi diwujudkan oleh pemerintah salah satunya adalah Saluran Irigasi Kalibawang yang terdapat di Kabupaten Kulon Progo. Rehabilitasi Saluran Induk Kalibawang pada tahun 2010 dan 2011 diharapkan masyarakat dapat merasakan dampaknya terhadap hasil pertanian mereka. Penelitian ini bertujuan mendeskripsikan pengaruh rehabilitasi Saluran Induk Kalibawang terhadap pengembangan ekonomi wilayah Kecamatan Kalibawang dengan melihat ekstensifikasi pertanian, intensifikasi pertanian, produksi padi, aktivitas pertanian hulu-hilir, pola dan struktur ruang. Penelitian ini menggunakan metode penelitian kuantitatif yang didukung analisis deskriptif serta teknis analisis keruangan superimpose. Temuan studi dari penelitian ini dapat disimpulkan bahwa rehabilitasi Saluran Induk Kalibawang berpengaruh positif terhadap pengembangan ekonomi wilayah Kecamatan Kalibawang Kabupaten Kulon Progo.

Kata kunci: rehabilitasi, irigasi, kalibawang, pengembangan wilayah

\footnotetext{
${ }^{1}$ Balai Besar Wilayah Sungai Serayu Opak, Direktorat Jenderal Sumber Daya Air, Kementerian Pekerjaan Umum

${ }^{2}$ Dosen Jurusan Perencanaan Wilayah dan Kota, Undip, Semarang, Jawa Tengah

Kontak Penulis : ndik.ndik@yahoo.com
} 


\section{PENDAHULUAN}

Infrastruktur mempunyai fungsi yang sangat penting dalam pengembangan suatu wilayah. Mengingat sebagian besar penduduk pedesaan di Indonesia bermata pencaharian sebagai petani, maka infrastruktur irigasi memiliki peran yang sangat penting dalam produksi hasil pertanian. Pemerintah dalam membangun infrastruktur irigasi telah mengeluarkan biaya yang tidak sedikit. Oleh karena itu keberadaan infrastruktur irigasi harus dikelola dengan baik. Menurut PP No. 20 tahun 2006 "Pengelolaan jaringan irigasi adalah kegiatan yang meliputi operasi, pemeliharaan, dan rehabilitasi jaringan irigasi di daerah irigasi."

Pembangunan infrastruktur irigasi diwujudkan oleh pemerintah salah satunya adalah Saluran Irigasi Kalibawang yang terdapat di Kabupaten Kulon Progo. Daerah Irigasi Kalibawang mempunyai luas 7.152 Ha untuk melayani area persawahan yang tersebar di 11 dari 12 kecamatan yang ada di Kabupaten Kulon Progo. Dengan demikian Saluran Irigasi Kalibawang mempunyai peranan penting untuk mengairi sawah di Kabupaten Kulon Progo dalam rangka pengembangan ekonomi khususnya di sektor pertanian. Oleh karena itu daerah irigasi yang dibangun tahun 1946 ini perlu dirawat dan dipelihara dengan baik. Perawatan tersebut telah diwujudkan oleh pemerintah melalui kegiatan rehabilitasi di saluran induk. Dengan direhabnya Saluran Induk Kalibawang maka diharapkan masyarakat dapat merasakan dampaknya terhadap hasil pertanian mereka. Dengan meningkatnya hasil produksi pertanian tersebut, diharapkan akan meningkatkan pendapatan petani serta berdampak pada pengembangan ekonomi wilayah di Kabupaten Kulon Progo.

Berdasarkan data dari BPS Kulon Progo, laju pertumbuhan PDRB tahun 2009 melambat 0,74 poin. Menurut BPS melambatnya laju pertumbuhan ini disebabkan karena melambatnya pertumbuhan pada sektor pertanian yang mempunyai kontribusi yang dominan pada total pembentukan PDRB. Hal tersebut tidak terlepas dari kontribusi masing-masing kecamatan, salah satunya adalah Kecamatan Kalibawang. Laju pertumbuhan PDRB sektor pertanian Kecamatan Kalibawang pada tahun 2009 mengalami penurunan sebesar 2,54 poin. Dengan adanya kegiatan rehabilitasi Saluran Induk Kalibawang dapat dilihat poduksi pertanian padi sebelum dan sesudah adanya kegiatan tersebut. Menurut data BPS Kulon Progo tahun 2011 produksi padi sawah di Kecamatan Kalibawang mengalami peningkatan yang cukup signifikan setelah adanya rehabilitasi, dimana produksi padi tahun 2009 sebesar 8.159,99 ton, tahun 2010 sebesar 8.447,71 ton, dan tahun 2011 sebesar 13.216,30 ton. Berdasarkan kondisi tersebut, perlu dilakukan penelitian agar dapat diketahui bagaimanakah pengaruh rehabilitasi Saluran Induk Kalibawang terhadap pengembangan ekonomi wilayah Kecamatan Kalibawang Kabupaten Kulon Progo. Variabel-variabel pengembangan ekonomi wilayah yang ingin diketahui pengaruhnya akibat rehabilitasi Saluran Induk Kalibawang adalah:

1. Ekstensifikasi pertanian, yaitu pengembangan suatu wilayah dengan cara menambah lahan sawah irigasi karena perluasan wilayah oncoran air irigasi.

2. Intensifikasi pertanian, yaitu pengembangan suatu wilayah dengan mengoptimalkan sarana dan prasarana pertanian yang telah ada.

3. Produksi padi, yaitu hasil yang diperoleh petani melalui kegiatan pertanian.

4. Aktivitas pertanian hulu dan hilir, yaitu semua aktivitas pertanian mulai dari pengadaan sarana produksi pertanian sampai dengan panen, pengolahan maupun pemasaran hasil pertanian. Aktivitas pertanian hulu: pemasaran saprodi pertanian, sedangkan aktivitas pertanian hilir: kegiatan industri penggilingan gabah.

5. Pola dan struktur ruang, yaitu penggunaan lahan pertanian dan jaringan sarana dan prasarana pertanian. 


\section{METODE PENELITIAN}

Metode penelitian yang digunakan dalam penelitian ini melalui metode kuantitatif yang didukung deskripsi untuk mendetailkan temuan lapangan yang dilengkapi dengan analisis keruangan. Menurut Singarimbun (1995) bahwa analisis data merupakan proses penyederhanaan data ke dalam bentuk yang lebih muda di baca dan diinterpretasikan. Data yang bersifat kuantitatif, diproses dengan beberapa cara antara lain (a) dijumlahkan, dibandingkan dengan jumlah yang diharapkan dan diperoleh prosentase, (b) dijumlahkan, diklasifikasikan sehingga merupakan suatu susunan urut data, untuk selanjutnya dibuat table atau diproses lebih lanjut menjadi perhitungan kesimpulan atau kepentingan visualisasi dan dengan bentuk grafik, dengan tujuan agar data ini memudahkan peneliti atau orang lain memahami hasil penelitian. Berdasarkan hal tersebut maka akan dapat dilakukan penafsiran terhadap data dan akan diperoleh kesimpulan dari fenomena yang sedang berlangsung. Pengertian Deskriptif adalah analisis serta menyajikan data dan fakta yang sudah terolah beserta penafsirannya, selain itu teknik ini digunakan untuk menganalisis data dengan cara: (a) menggambarkan data yang telah terkumpul, (b) menginterpretasikan kondisi atau hubungan yang ada, (c) menggambarkan proses yang sedang berlangsung, (d) menggambarkan kecendrungan atau pendapat yang sedang berkembang.

Adapun cara pengambilan sampel dalam penelitian ini menggunakan Proportionate Stratified Purposive Sampling, yaitu peneliti secara sengaja menentukan sampel yang akan diambil kemudian dibagi strata-strata atau sub populasi berdasarkan homogenitas, kemudian pengambilan sampel dilakukan dalam setiap strata secara proporsional. Pengambilan sampel dalam penelitian ini terbagi dalam sub populasi yaitu petani lahan kecil: $<0,5 \mathrm{Ha}$, petani lahan sedang: 0,5 - $1 \mathrm{Ha}$, dan petani lahan besar: $\geq 1 \mathrm{Ha}$. Melalui perhitungan proporsi jumlah sampel setiap strata dapat ditetapkan jumlah sampel petani lahan kecil sebesar 58 responden, petani lahan sedang sebesar 27 responden, dan petani lahan besar sebesar 11 responden.

\section{GAMBARAN UMUM}

Kabupaten Kulon Progo Secara geografis terletak antara $7^{\circ} 38^{\prime} 42^{\prime \prime}-7^{\circ} 59^{\prime} 3^{\prime \prime}$ Lintang Selatan dan $110^{\circ} 1^{\prime} 37^{\prime \prime}$ - 110 $10^{\circ} 26^{\prime \prime}$ Bujur Timur dan merupakan wilayah bagian Provinsi Daerah Istimewa Yogyakarta yang dibatasi oleh:

Sebelah Barat : : Kabupaten Purworejo, Provinsi Jawa Tengah.

Sebelah Timur : : Kabupaten Sleman dan Bantul Prov. D. I. Yogyakarta.

Sebelah Utara $\quad$ : Kabupaten Magelang, Provinsi Jawa Tengah.

Sebelah Selatan : : Samudera Hindia.

Luas area kabupaten Kulo Progo adalah 58.628,311 Ha yang meliputi 12 kecamatan, 88 desa (13 desa perkotaan dan 75 desa perdesaan), 930 Pedukuhan, 1.825 Rukun Warga, dan 4.469 Rukun Tetangga. Secara umum ekosistem wilayah Kabupaten Kulon Progo dapat dibedakan menjadi 3 wilayah ekosistem, yaitu ekosistem pegunungan, ekosistem perbukitan dan ekosistem dataran.

Saluran Induk Kalibawang dibangun pada tahun 1946. Air diambil dari Sungai Progo melalui bangunan pengambilan bebas (free intake) yang terletak pada belokan luar sisi kanan alur sungai. Bangunan intake tersebut terletak di Desa Banjarharjo, Kecamatan Kalibawang. Pada awal pembangunannya, panjang Saluran Induk Kalibawang hanya $12 \mathrm{~km}$. Pada tahun 1976 dilakukan penambahan dan perbaikan bangunan-bangunan bagi dan sadap serta 
perpanjangan saluran induk dari $12 \mathrm{~km}$ menjadi $24 \mathrm{~km}$. Pada tahun 1989 di lakukan service maintenance, dan pada tahun 2000 dilakukan pemindahan jalur Talang Bowong, di sekitar Km. 15, karena kondisi talang yang lama sudah bergeser dan bocor. Sampai saat ini di sepanjang Saluran Induk Kalibawang terdapat 289 bangunan.

Secara administratif lokasi pekerjaan rehabilitasi Saluran Induk Kalibawang sebagian besar berada di wilayah Kecamatan Kalibawang Kabupaten Kulonprogo, yang tersebar di beberapa desa antara lain Desa Banjaroyo, Banjarharjo, Banjarasri, dan Banjararum. Panjang Saluran Induk Kalibawang yang berada di Kecamatan Kalibawang adalah $17 \mathrm{Km}$. Jenis kegitan perbaikan meliputi pembersihan sedimen, perbaikan pintu air, perbaikan dinding saluran yang bocor, dan perbaikan talang air.

\section{KAJIAN TEORI}

Pengembangan ekonomi wilayah, yaitu suatu usaha mengembangkan dan meningkatkan ketergantungan serta interaksi antara system ekonomi, masyarakat, dan lingkungan hidup dengan tujuan untuk mencapai pertumbuhan ekonomi dan mendorong pemerataan pertumbuhan sehingga dapat mengurangi disparitas regional (Tukiyat, 2002). Perkembangan suatu wilayah juga dipengaruhi oleh aspek eksternal, yaitu globalisasi ekonomi dan kerjasama ekonomi antar negara. Kedua hal tersebut akan memicu kebutuhan pengembangan ruang dan prasarana suatu wilayah. Kebutuhan prasarana tersebut dapat diwujudkan melalui pola intensifikasi, ekstensifikasi dan invasi. Pola intensifikasi merupakan upaya untuk mengembangkan suatu wilayah dengan cara mengoptimalkan sarana dan prasarana yang sudah ada. Sebagai contoh saluran irigasi dilakukan direhabilitasi, sehingga penggunaanya dapat dioptimalkan. Pola ekstensifikasi dapat dikatakan suatu langkah untuk mengembangkan suatu wilayah dengan cara menambah sarana dan prasarana yang ada. Sebagai contoh untuk mengembangkan pertanian wilayah dilakukan penambahan/membangun saluran irigasi baru (Riyadi, 2002).

Berbicara tentang pengembangan wilayah tidak bias lepas dari wilayah itu sendiri. Wilayah merupakan kumpulan entitas spasial yang homogeny dalam hal variable tertentu dan terdapat hubungan secara intensif antara variable satu dengan lainnya (Siebert dalam Baja, 2012). Dengan demikian wilayah harus dipandang sebagai suatu ruang tertentu yang memiliki sejumlah variable di dalamnya, dan setiap variabel tersebut memiliki hubungan secara fungsional. Variabel utama dalam ruang tersebut adalah tata guna lahan (land use) baik alami maupun buatan dan secara spasial memiliki hubungan-hubungan sosial, ekonomi, dan lingkungan. Fungsi lahan dalam pengembangan wilayah adalah untuk dimanfaatan berproduksi secara optimal. Berproduksi yang meliputi kegiatan pertanian, kehutanan, perikanan, dll. Selain itu juga berhubungan dengan perumahan, industri, transportasi, rekreasi, dan sarana prasarana lainnya. Agar tata guna lahan tersebut dapat dimanfaatkan secara lebih efisien, adil, dan berkelanjutan perlu diatur tentang pola dan struktur ruangnya (Baja, 2012). Menurut UU No. 26 tahun 2007 tentang Penataan Ruang menjelaskan bahwa pola ruang adalah distribusi peruntukan ruang dalam suatu wilayah yang meliputi peruntukan ruang untuk fungsi lindung dan peruntukan ruang untuk fungsi budi daya. Sedangkan struktur ruang adalah susunan pusat-pusat permukiman dan sistem jaringan prasarana dan sarana yang berfungsi sebagai pendukung kegiatan social ekonomi masyarakat yang secara hierarkis memiliki hubungan fungsional.

Pengertian irigasi menurut Peraturan Pemerintah No. 20 Tahun 2006 tentang Irigasi memiliki 
pengertian usaha penyediaan, pengaturan, dan pembuangan air irigasi untuk menunjang pertanian yang jenisnya meliputi irigasi permukaan, irigasi rawa, irigasi air bawah tanah, irigasi pompa, dan irigasi tambak. Sedangkan rehabilitasi jaringan irigasi adalah kegiatan perbaikan jaringan irigasi guna mengembalikan fungsi dan pelayanan irigasi seperti semula.

Saluran irigasi merupakan faktor penting yang mampu meningkatkan produksi pertanian khususnya subsektor pertanian tanaman pangan yang selanjutnya mampu menaikkan pendapatan dan memberikan pengaruh positif terhadap pengembangan ekonomi (Setyohadi dalam Situmorang, 2011).

Menurut Fatah (2006) pertanian mempunyai keterkaitan dengan berbagai aspek perekonomian lainnya, maka pembangunan pertanian merupakan salah satu penentu pertumbuhan ekonomi, termasuk di dalamnya non-pertanian di pedesaan. Dengan demikian, pembangunan pertanian menjadi bagian yang penting bagi upaya-upaya peningkatan pendapatan masyarakat. Selain itu pertanian dianggap sebagai sektor pemimpin (leading sector) yang diharapkan mendorong perkembangan sektor-sektor lainnya. Hal tersebut sama seperti yang diungkapkan oleh Syahza (2005), bahwa bila dicermati usaha pertanian memiliki dampak terhadap timbulnya usaha-usaha baru seperti pedagangan hasil-hasil pertanian maupun kebutuhan operasional pertanian. Selain itu peningkatan jumlah produksi pertanian dapat memicu perluasan sektor industri, seperti munculnya industri rumah tangga yang mengolah hasil-hasil produksi pertanian maupun munculnya industri penggilingan gabah menjadi beras. Menurut Soenarno (2003) Kawasan agropolitan dicirikan dengan kawasan pertanian yang tumbuh dan berkembang karena berjalannya sistem dan usaha agribisnis di pusat agropolitan yang diharapkan dapat mengembangan wilayah. Hal tersebut dapat dilihat dari berkembangnya kegiatan agribisnis hulu (penyediaaan sarana pertanian) dan hilir (processing). Maulidah (2012) mengungkapkan bahwa aktivitas petanian hulu merupakan semua aktivitas yang meliputi pengadaaan sarana produksi pertanian antara lain terdiri dari, bibit, pupuk, lembaga kredit, obat pemberantas hama, alat-alat, dan mesin. Pelaku kegiatan pengadaan dan penyaluran sarana produksi pertanian adalah perorangan, perusahaan swasta, pemerintah, dan koperasi. Sedangkan aktivitas pertanian hilir adalah semua aktivitas yang meliputi pengumpulan, pengolahan, dan distribusi hasil pertanian. Pelaku dalam hal ini adalah pengumpul produk, pengolah, pedagang, dan penyalur ke konsumen.

\section{ANALISIS}

\section{Analisis Pengaruh Rehabilitasi Saluran Induk Kalibawang terhadap Ekstensifikasi Pertanian}

Kegiatan ekstensifikasi merupakan upaya untuk mengembangkan suatu wilayah dengan cara menambah sarana dan prasarana baru. Kegiatan ektensifikasi yang terkait dengan pertanian di Kecamatan Kalibawang adalah perluasan lahan pertanian. Perluasan lahan yang erat kaitannya dengan kegiatan rehabilitasi Saluran Induk Kalibawang adalah perluasan lahan sawah irigasi yang memanfaatkan air dari Irigasi Kalibawang. Telah diketahui bahwa rehabilitasi Saluran Induk Kalibawang membawa pengaruh terhadap peningkatan jumlah debit air pada saluran induk. Dengan demikian pelayan air untuk proses produksi padi semakin lancar.

Jika melihat data luas sawah irigasi di Kecamatan Kalibawang antara sebelum dan sesudah rehabilitasi Saluran Induk Kalibawang, maka terdapat perbedaan dimana luas tersebut bertambah. Bahwa sebelum rehabilitasi luas sawah irigasi di Kecamatan Kalibawang seluas 690 Ha dan setelah rehabilitasi luasnya bertambah menjadi 700 Ha. Dengan demikian terdapat 
perluasan lahan sawah irigasi sebesar $10 \mathrm{Ha}$. Perluasan lahan sawah irigasi terjadi pada tahun 2012 atau kurang lebih 1 tahun setelah kegiatan rehabilitasi Saluran Induk Kalibawang. Perluasan lahan tersebut tepatnya di Desa Banjararum Kecamatan Kalibawang. Selain itu juga pada lahan tersebut telah berdiri P3A baru dengan nama Toya Nugraha dan mempunyai petak tersier tersendiri dengan nama Petak Tersier Pundak.

Dengan demikian kegiatan rehabilitasi Saluran Induk Kalibawang telah membawa pengaruh terhadap kegiatan ekstensifikasi pertanian. Seperti apa yang dikatakan Riyadi (2002) bahwa salah satu cara untuk mengembangkan suatu wilayah dapat dicapai dengan cara ekstensifikasi. Dengan demikian dapat dikatakan bahwa secara tidak langsung kegiatan rehabilitasi Saluran Induk Kalibawang merupakan salah satu cara upaya untuk mengembangkan ekonomi wilayah Kecamatan Kalibawang. Upaya tersebut berupa perluasan lahan sawah irigasi sebesar 10 Ha atau $1,45 \%$.

\section{Analisis Pengaruh Rehabilitasi Saluran Induk Kalibawang terhadap Intensifikasi Pertanian}

Intensifikasi merupakan salah satu usaha untuk meningkatkan hasil dengan cara mengoptimalkan sarana dan prasarana yang sudah ada untuk memperoleh hasil yang optimal. Intensifikasi sangat dianjurkan untuk diterapkan agar mendapatkan produk atau hasil lebih banyak dengan kualitas yang lebih baik. Jika melihat pengaruh rehabilitasi Saluran Induk Kalibawang, maka intensifikasi dalam hal ini berfokus pada pengoptimalan sarana dan prasarana irigasi serta merubah pola tanam.

Seperti yang telah diketahui sebelumnya bahwa rehabilitasi Saluran Induk Kalibawang membawa pengaruh terhadap peningkatan jumlah debit air pada saluran induk. Sehingga peningkatan debit air tersebut juga akan mempengaruhi debit air pada saluran sekunder dan tersier. Dimana debit air pada saluran sekunder juga mengalami peningkatan. Setelah rehabilitasi Saluran Induk Kalibawang selesai terdapat kegiatan lanjutan yaitu perbaikan saluran sekunder Irigasi Kalibawang. Kondisi saluran sekunder Irigasi Kalibawang mengalami pendangkalan dan tidak optimal menampung debit air. Sehingga pada tahun 2011 dan 2012 diadakan rehabilitasi untuk memperbaiki saluran sekunder Irigasi Kalibawang. Kegiatan tersebut dalam rangka optimalisasi Sistem Irigasi Kalibawang. Sistem irigasi itu sendiri di dalamnya memuat tentang saluran pimer, saluran sekunder, dan saluran tersier bahkan kwarter. Mengingat saluan primer telah direhabilitasi maka akan lebih optimal jika diikuti oleh rehabilitasi saluran sekunder. Hal tersebut juga diterapkan pada Sistem Irigasi Kalibawang.

Terdapat peningkatan kondisi saluran sekunder Irigasi Kalibawang antara sebelum dan setelah direhab. Dimana sebelum direhab sebesar $60 \%$ kondisi saluran sekunder dalam keadaan baik. Sementara setelah direhab meningkat menjadi $70 \%$ kondisi saluran sekunder dalam keadaan baik. Begitu pula dengan saluran sekunder dengan kondisi rusak berat mengalami penurunan. Dimana sebelum direhab sebesar $10 \%$ kondisi saluran sekunder dalam keadaan rusak berat. Sementara setelah direhab menurun menjadi $5 \%$ kondisi saluran sekunder dalam keadaan rusak berat.

Rehabilitasi Saluran Induk Kalibawang secara tidak langsung membawa pengaruh terhadap terlaksananya kegiatanintensifikasi pertanian. Wujud nyata kegiatan intensifikasi pertanian tersebut berupa perbaikan saluran sekunder Irigasi Kalibawang. Dengan diperbaikinya saluran sekunder menjadikan kondisi bangunan semakin membaik. Hal tersebut sesuai dengan Renstra Perluasan Areal Pertanian Baru Dalam Rangka Mendukung Prioritas Nasional Ketahanan Pangan oleh Bappenas (2010) bahwa infrastruktur yang peranannya sangat menonjol di 
pertanian adalah irigasi. Dengan adanya irigasi yang baik maka pasokan air untuk tanaman meningkat dan lebih reliabel sehingga intensifikasi usahatani lebih mudah diterapkan dan karena itu produktivitas dapat ditingkatkan. Kondisi bangunan saluran sekunder semakin membaik sebesar $10 \%$. Sampai saat penelitian ini dilakukan, masih berlangsung proses kegiatan rehabilitasi saluran sekunder Irigasi Kalibawang. Dengan demikian kondisi saluran sekunder nantinya akan semakin membaik.

Intensifikasi pertanian juga dapat diwujudkan melalui optimalisasi pola tanam. Pola tanam sawah irigasi sebelum rehabilitasi Saluran Induk Kalibawang di Kecamatan Kalibawang adalah padi-padi-palawija, dan setelah dilakukan rehabilitasi terdapat beberapa petak tersier yang mengalami perubahan pola tanam. Mayoritas pola tanam sawah irigasi di Kecamatan Kalibawang tidak mengalami perubahan. Dimana $88,84 \%$ luas sawah irigasi di Kecamatan Kalibawang tidak mengalami perubahan pola tanam. Meskipun demikian terdapat perubahan pola tanam pada area lahan yang mengalami perluasan sawah irigasi seluas $10 \mathrm{Ha}$. Pola tanam pada area perluasan sawah irigasi tersebut semula adalah padi-palawija-palawija menjadi padipadi-palawija. Sehingga dapat dikatakan bahwa terdapatpeningkatan pola tanam menjadi padi- padi-palawija sebesar $1,45 \%$ dari total luas sawah irigasi di Kecamatan Kalibawang. Terdapat $77 \mathrm{Ha}$ atau 11,16\% atau sawah irigasi mengalami perubahan pola tanam mejadi palawija-palawija-palawija. Hal tersebut terjadi karena sawah seluas $77 \mathrm{Ha}$ tersebut tertimbun lahar dingin Gunung Merapi sehingga belum bisa ditanami padi.

\section{Analisis Pengaruh Rehabilitasi Saluran Induk Kalibawang terhadap Produksi Padi}

Peningkatan produksi padi dapat diasumsikan sebagai ukuran peningkatan pendapatan petani. Jika secara umum pendapatan petani dalam suatu wilayah mengalami peningkatan maka perekonomian wilayah tersebut semakin membaik. Berdasarkan hasil jawabahan 96 responden diketahui bahwa 86 responden menyatakan produksi padi mereka mengalami peningkatan. Peningkatan produksi padi tersebut dengan rincian sebesar 84 responden atau $87,5 \%$ menyatakan produksi padi mereka meningkat $1 \%$ s.d 25\%, 2 responden atau 2,1\% menyatakan produksi padi mereka mengalami peningkatan $26 \%$ s.d $50 \%$. Sedangkan sisanya sebesar 10 responden atau 10,4\% menyatakan produksi padi mereka tidak mengalami peningkatan.

Mayoritas pendapatan responden mengalami peningkatan setelah rehabilitasi Saluran Induk Kalibawang. Terdapat 7 responden atau sebesar 7,3\% menyatakan pendapatan mereka tetap atau tidak mengalami peningkatan. Responden yang menyatakan pendapatan mereka tetap pada umumnya produksi padi mereka tidak mengalami peningkatan. Sedangkan sebesar 89 responden atau $92,7 \%$ menyatakan pendapatan mereka mengalami peningkatan. Responden yang menyatakan pendapatan mereka tetap pada umumnya produksi padi mereka tidak mengalami peningkatan. Sedangkan sebesar 89 responden atau 92,7\% menyatakan pendapatan mereka mengalami peningkatan. Responden yang menyatakan pendapatan mereka meningkatan dengan rincian sebesar 45 responden menyatakan meningkat $1 \%$ s.d $25 \%$, 43 responden menyatakan meningkat $26 \%$ s.d 50\%, dan sisanya hanya terdapat 1 responden menyatakan meningkat lebih dari $50 \%$.

Rehabilitasi Saluran Induk Kalibawang telah membawa pengaruh terhadap peningkatan produksi padi di Kecamatan Kalibawang. Hal tersebut sesuai dengan pernyataan Setyohadi dalam Situmorang (2011) bahwa kinerja jaringan irigasi lebih dominan peranannya dalam hal peningkatan produksi padi dan palawija. Dengan meningkatnya produksi padi tersebut dapat diasumsikan pendapatan yang diperoleh petani semakin meningkat karena harga gabah antara sebelum dan setelah rehabilitasi Saluran Induk Kalibawang relatif stabil. Hal tersebut sesuai dengan Renstra Perluasan Areal Pertanian Baru Dalam Rangka Mendukung Prioritas 
Nasional Ketahanan Pangan oleh Bappenas (2010) bahwa ketersediaan infrastruktur pertanian dapat mempengaruhi perkembangan produksi pertanian yang terwujud dalam peningkatan produksi serta berpengaruh terhadap pendapatan rumah tangga petani. Pernyataan 96 responden dapat diketahui bahwa $89,6 \%$ responden menyatakan produksi padi mereka meningkat dan $92,7 \%$ responden menyatakan pendapatan mereka meningkat setelah adanya rehabilitasi Saluran Induk Kalibawang.

\section{Analisis Pengaruh Rehabilitasi Saluran Induk Kalibawang terhadap Aktivitas Pertanian Hulu- Hilir}

Aktivitas pertanian hulu meliputi pengadaan sarana produksi pertanian, dalam hal ini produksi padi antara lain terdiri dari pengadaan bibit, pupuk, obat pemberantas hama dan penyakit, lembaga kredit, bahan bakar, alat-alat, mesin, dan peralatan produksi pertanian. Pelaku-pelaku kegiatan pengadaan dan penyaluran sarana produksi adalah perorangan, perusahaan swasta, pemerintah, koperasi. Betapa pentingnya subsistem ini mengingat perlunya keterpaduan dari berbagai unsur itu guna mewujudkan sukses produksi padi.

Terdapat tiga pelaku usaha dalam penyaluran saprodi pertanian agar sampai ke tangan petani. Distributor merupakan pelaku pertama dalam penyaluran saprodi pertanian. Kegiatan utama distributor adalah melayani pengadaan pupuk oleh agen pengecer. Distributor pupuk di Kecamatan Kalibawang hanya terdapat satu tempat yaitu di Ibu Kota Kecamatan Kalibawang di Banjararum. Kedua adalah agen pengecer adalah agen resmi dan mempunyai izin usaha untuk menyalurkan pupuk kepada petani. Antara sebelum dan setelah rehabilitasi Saluran Induk Kalibawang jumlah agen pengecer di Kecamatan Kalibawang terdapat 4 agen atau tidak mengalami perubahan. Jumlah tersebut sama dengan jumlah desa yang ada di Kecamatan Kalibawang, karena masing-masing desa hanya terdapat 1 agen pengecer resmi. Ketiga adalah jasa pengedar yaitu pelaku usaha penyaluran saprodi pertanian kepada para petani dengan menawarkan jasa pengadaan pupuk dan diantar sampai lokasi sawah para petani. Jumlah jasa pengedar di Kecamatan Kalibawang sebelum rehabilitasi tedapat 10 tempat sedangkan setelah rehabilitasi Saluran Induk Kalibawang bertambah menjadi 18 tempat.

Jumlah pelaku usaha jasa pengedar saprodi pertanian mengalami perkembangan yang pesat antara sebelum dan setelah rehabilitasi Saluaran Induk Kalibawang. Lain halnya dengan jumlah distributor dan agen pengecer tidak mengalami perubahan. Penambahan jumlah pelaku usaha jasa pengedar terbanyak terdapat di Desa Banjarasri dan Banjarharjo. Jumlah pelaku usaha jasa pengedar saprodi di Desa Banjarasri sebelum rehabilitasi terdapat 2 meningkat menjadi 5 pelaku usaha setelah rehabilitasi atau mengalami peningkatan sebesar $150 \%$. Jumlah pelaku usaha jasa pengedar saprodi di Desa Banjarharjo sebelum rehabilitasi terdapat 3 meningkat menjadi 6 pelaku usaha setelah rehabilitasi atau mengalami peningkatan sebesar $100 \%$. Jumlah pelaku usaha jasa pengedar saprodi di Desa Banjararum sebelum rehabilitasi terdapat 3 meningkat menjadi 5 pelaku usaha setelah rehabilitasi atau mengalami peningkatan sebesar 66,67\%. Sedangkan jumlah pelaku usaha jasa pengedar saprodi di Desa Banjaroyo tidak mengalami perubahan antara sebelum dan setelah rehabilitasi Saluran Induk Kalibawang.

Secara tidak langsung kegiatan rehabilitasi Saluran Induk Kalibawang telah membawa pengaruh terhadap peningkatan jumlah tempat pemasaran saprodi pertanian khususnya jumlah pelaku usaha jasa pengedar saprodi pertanian. Hal tersebut sesuai dengan pernyataan Soenarno (2003) bahwa perkembangan kawasan pertanian (agropolitan) dicirikan dengan berkembangnya kegiatan agribisnis hulu dan hilir. Selain itu Syahza (2005) juga mengungkapkan bahwa bila dicermati usaha pertanian memiliki dampak terhadap timbulnya usaha-usaha baru seperti perdagangan hasil-hasil pertanian maupun kebutuhan operasional 
(saprodi) pertanian. Dapat diketahui bahwa jumlah total secara keseluruhan pelaku usaha jasa pengedar saprodi pertanian sebelum rehabilitasi terdapat 10 meningkat menjadi 18 pelaku usaha setelah rehabilitasi Saluran Induk Kalibawang atau meningkat sebesar $80 \%$.

Aktivitas pertanian hilir meliputi pengolahan dan pemasaran produk pertanian. Pengolahan hasil produk pertanian dapat berupa usaha industri penggilingan gabah menjadi beras. Para pelaku usaha tersebut mempunyai peran amat penting bila ditempatkan di pedesaan karena dapat menjadi motor penggerak roda perekonomian di pedesaan, dengan cara menyerap/menciptakan lapangan kerja sehingga dapat meningkatkan pendapatan dan kesejahteraan masyarakat pedesaan.

Seperti yang telah diketahui setelah rehabilitasi Saluran Induk Kalibawang produksi padi di Kecamatan Kalibawang mengalami peningkatan. Peningkatan produksi padi tersebut menyebabkan jumlah gabah yang diolah/digiling menjadi beras juga meningkat. Hal tersebut ikut mempengaruhi kegiatan industri penggilingan gabah di Kecamatan Kalibawang. Secara umum industri penggilingan gabah di Kecamatan Kalibawang dibedakan menjadi 2 jenis yaitu industri penggilingan gabah mesin duduk dan mesin keliling. Industri penggilingan gabah mesin duduk adalah usaha yang dilakukan tidak bias berpindah tempat atau menetap disuatu tempat. Sedangkan industri penggilingan gabah mesin keliling adalah usaha yang dilakukan dapat berpindah tempat dan keliling dari kampong ke kampung.

Jumlah industri penggilingan gabah di semua desa mengalami peningkatan setelah rehabilitasi Saluran Induk Kalibawang. Peningkatan terbesar dialami oleh Desa Banjararum, dimana sebelumnya terdapat 7 meningkat menjadi 11 industri penggilingan gabah atau meningkat sebesar 57,14\%. Peningkatan terbesar kedua dialami oleh Desa Banjarasri, dimana sebelumnya terdapat 6 meningkat menjadi 9 industri penggilingan gabah atau meningkat sebesar $50 \%$. Untuk Desa Banjarharjo dan Banjaroyo juga mengalami peningkatan sebesar 33,33\%.

Berdasarkan jenis mesin yang digunakan industri penggilingan gabah, maka peningkatan terbesar dialami oleh industri penggilingan gabah mesin keliling. Secara keseluruhan di Kecamatan Kalibawang penggilingan mesin keliling sebelumnya terdapat 6 meningkat menjadi 13 industri penggilingan setelah rehabilitasi atau meningkat sebesar $116,67 \%$. Sedangkan industri penggilingan mesin duduk sebelumnya terdapat 16 meningkat menjadi 19 industri penggilingan setelah rehabilitasi atau meningkat sebesar $18,75 \%$. Jika melihat jumlah total antara mesin duduk dan keliling maka sebelumya terdapat 22 meningkat menjadi 32 industri penggilingan gabah setelah rehabilitasi Saluran Induk Kalibawang. Dengan demikian secara tidak langsung Rehabilitasi Saluran Induk Kalibawang telah memberikan pengaruh terhadap peningkatan industri penggilingan gabah sebesar 43,45\%. Hal tersebut sesuai dengan pernyataan Soenarno (2003) bahwa perkembangan kawasan pertanian (agropolitan dicirikan dengan) berkembangnya kegiatan agribisnis hulu dan hilir. Syahza (2005) juga mengatakan bahwa peningkatan produksi pertanian dapat memicu perluasan sektor industri pengolahan hasil-hasil produksi pertanian.

\section{Analisis Pengaruh Rehabilitasi Saluran Induk Kalibawang terhadap Pola dan Struktur Ruang}

Seperti telah diketahui bahwa pola ruang dapat dikatakan distribusi peruntukan ruang dalam suatu wilayah untuk fungsi lindung dan fungsi budi daya. Dalam hal ini pola ruang berfokus pada fungsi budi daya khususnya penggunaan ruang untuk pertanian padi sawah irigasi di Kecamatan Kalibawang. Penggunaan ruang untuk sawah Irigasi Kalibawang antara sebelum dan setelah rehabilitasi Saluran Induk Kalibawang mengali perubahan. Berdasarkan Perbup Kulon Progo No. 28 Tahun 2012 Tentang Tata Tanam Tahunan Periode 2012 - 2013 penggunaan 
ruang untuk sawah irigasi meningkat $10 \mathrm{Ha}$ menjadi $700 \mathrm{Ha}$. Meskipun demikian secara fisik dilapangan luas sawah irigasi tersebut tidak sepenuhnya bisa ditanami padi karena terdapat sawah yang masih tertimbun material lahar dingin Gunung Merapi.

Meskipun rehabilitasi Saluran Induk Kalibawang belum mampu mengembalikan sawah irigasi yang tertimbun lahar dingin pada kondisi semula, tetapi mampu mengubah pola ruang untuk dijadikan sawah irigasi. Seperti telah disebutkan sebelumnya, telah terjadi perubahan fungsi lahan sawah tadah hujan dan tegalan seluas $10 \mathrm{Ha}$ menjadi sawah irigasi. Seperti yang dikatakan Baja (2012) fungsi lahan dalam pengembangan wilayah adalah untuk dimanfaatkan berproduksi secara optimal, tetapi agar tata guna lahan tersebut dapat dimanfaatkan secara lebih efisien, adil, dan berkelanjutan perlu diatur pola ruangnya. Artinya bahwa Rehabilitasi Saluran Induk Kalibawang secara tidak langsung merupakan salah satu cara untuk mengembangkan ekonomi wilayah Kecamatan Kalibawang melalui pengaruhnya terhadap perubahan pola ruang penggunaan lahan untuk sawah irigasi. Dimana pengaruh tersebut dapat dirasakan terhadap peningkatan pemanfaatan ruang untuk sawah irigasi di Kecamatan Kalibawang seluas $10 \mathrm{Ha}$ atau $1,45 \%$.

Struktur ruang merupakan susunan pusat-pusat permukiman dan sistem jaringan prasarana dan sarana yang berfungsi sebagai pendukung kegiatan sosial ekonomi masyarakat. Struktur ruang disini berfokus pada tempat pemasaran saprodi pertanian, tempat industri penggilingan gabah, dan sistem jaringan sarana dan prasarana irigasi yang memanfaatkan air dari Saluran Induk Kalibawang.

Seperti pada sub bab sebelumnya tentang aktivitas pertanian hulu-hilir telah diketahui perubahan jumlah tempat pemasaran saprodi pertanian dan industri penggilingan gabah antara sebelum dan setelah rehabilitasi Saluran Induk Kalibawang. Dengan perubahan jumlah tersebut maka struktur ruang untuk sarana dan prasarana pertanian di Kecamatan Kalibawang ikut berubah. Lahar dingin yang menutupi sawah irigasi seluas 77 Ha juga telah membuat rusak sarana dan prasarana irigasinya. Sebagian saluran sekunder dan seluruh saluran tersier sawah irigasi yang tertimbun lahar dingin telah rusak.

Perubahan struktur ruang untuk sarana dan prasarana irigasi terjadi antara sebelum dan setelah Rehabilitasi Saluran Induk Kalibawang. Saluran sekunder dan tersier sepanjang 3.000 meter hilang atau rusak tertimbun lahar dingin Gunung Merapi. Artinya bahwa Rehabilitasi Saluran Induk Kalibawang belum dapat dirasakan pengaruhnya terhadap pemulihan struktur ruang khususnya sarana dan prasarana irigasi sepanjang $3.000 \mathrm{~m}$ atau sebesar $5,89 \% \mathrm{di}$ Kecamatan Kalibawang yang terkena lahar dingin Gunung Merapi kembali pada kondisi semula. Namun demikian rehabilitasi Saluran Induk Kalibawang berpengaruh terhadap susunan sarana dan prasarana Irigasi Kalibawang. Peningkatan jumlah saluran tersier sepanjang 400 meter terja di pada perluasan sawah irigasi seluas 10 Ha. Selain itu tempat sarana dan prasarana untuk kegiatan pertanian juga mengalami peningkatan, yaitu jumlah tempat pemasaran saprodi pertanian meningkat sebesar $80 \%$ dan jumlah industry penggilingan gabah meningkat sebesar $43,45 \%$. Seperti apa yang dikatakan Baja (2012) bahwa fungsi lahan dalam pengembangan wilayah berhubungan dengan perumahan, industri, transportasi, rekreasi, sarana prasarana lainnya, karena secara spasial memiliki hubungan dalam aktivitas sosial, ekonomi, dan lingkungan. Oleh karena itu agar aktivitas tersebut dapat berjalan efisien, adil, dan berkelanjutan perlu diatur struktur ruangnya. Artinya bahwa Rehabilitasi Saluran Induk Kalibawang secara tidak langsung merupakan salah satu cara untuk mengembangkan ekonomi wilayah Kecamatan Kalibawang melalui pengaruhnya terhadap perubahan struktur ruang sarana prasana pertanian. 


\section{Pengaruh Rehabilitasi Saluran Induk Kalibawang terhadap Pengembangan Ekonomi Wilayah Kecamatan Kalibawang Kabupaten Kulon Progo}

Pada analisis yang telah dilakukan sebelumnya merupakan pembahasan tentang pengaruh rehabilitasi Saluran Induk Kalibawang terhadap variabel- variabel pengembangan ekonomi wilayah. Adapun variable yang dianalisis adalah ekstensifikasi pertanian, intensifikasi pertanian, produksi padi, aktivitas pertanian hulu-hilir, serta pola dan struktur ruang. Setelah dilakukan analisis maka dapat dikatakan bahwa rehabilitasi Saluran Induk Kalibawang berpengaruh terhadap pengembangan ekonomi wilayah di Kecamatan Kalibawang. Hal tersebut sesuai dengan pernyataan Setyohadi dalam Situmorang (2011) bahwa saluran irigasi merupakan faktor penting yang mampu meningkatkan produksi pertanian yang selanjutnya mampu menaikkan pendapatan dan memberikan pengaruh positif terhadap pengembangan ekonomi.

\section{KESIMPULAN}

Dari hasil analisis yang telah dilakukan sebelumnya mengenai pengaruh rehabilitasi Saluran Induk Kalibawang terhadap pengembangan ekonomi wilayah di Kecamatan Kalibawang, dapat diambil kesimpulan sebagai berikut:

1. Rehabilitasi Saluran Induk Kalibawang telah membuat kondisi bangunan fisik saluran semakin membaik dan debit air semakin meningkat.

2. Rehabilitasi saluran Induk Kalibawang berpengaruh secara tidak langsung terhadap kegiatan ekstensifikasi atau perluasan lahan pertanian. Dimana antara sebelum dan setelah rehabilitasi luas sawah irigasi meningkat sebesar $10 \mathrm{Ha}$ atau 1,45\% dari total sawah irigasi di Kecamatan Kalibawang.

3. Rehabilitasi saluran Induk Kalibawang berpengaruh secara tidak langsung terhadap kegiatan intensifikasi atau perbaikan sarana dan prasarana irigasi khususnya saluran sekunder Irigasi Kalibawang. Dimana antara sebelum dan setelah rehabilitasi kondisi saluran sekunder Irigasi Kalibawang semakin membaik sebesar $10 \%$.

4. Peningkatan produksi padi di Kecamatan Kalibawang yang disebabkan adanya Rehabilitasi Saluran Induk Kalibawang telah membawa pengaruh terhadap peningkatan pendapatan petani. Sebesar $89,6 \%$ responden menyatakan pendapatan mereka meningkat sedangkan 10,4\% menyatakan pendapatan mereka tidak mengalami peningkatan. Terdapat $87,5 \%$ responden menyatakan pendapatan mereka naik $1 \%$ s.d $25 \%$.

5. Adanya rehabilitasi Saluran Induk Kalibawang telah membawa pengaruh terhadap peningkatan pelaku usaha pemasaran saprodi pertanian khususnya jasa pengedar pupuk. Jumlah pelaku jasa pengedar saprodi di Kecamatan Kalibawang sebelum rehabilitasi sebesar 10 meningkat menjadi 18 pelaku setelah rehabilitasi atau meningkat sebesar $80 \%$. Adanya kegiatan rehabilitasi saluran Induk Kalibawang secara tidak langsung telah membawa pengaruh terhadap peningkatan jumlah industri penggilingan gabah di Kecamatan Kalibawang. Jumlah industri penggilingan gabah di Kecamatan Kalibawang sebelum rehabilitasi sebesar 22 meningkat menjadi 32 industri penggilingan setelah rehabilitasi atau meningkat sebesar $43,45 \%$.

6. Rehabilitasi Saluran Induk Kalibawang berpengaruh terhadap pola ruang di Kecamatan Kalibawang yaitu penggunaan lahan untuk sawah irigasi meningkat seluas $10 \mathrm{Ha}$ atau 1,45\% meskipun terdapat 77 Ha yang tertimbun lahar dingin Gunung Merapi. Kegiatan rehabilitasi Saluran Induk Kalibawang tersebut berpengaruh terhadap struktur ruang di Kecamatan Kalibawang terutama sarana dan prasarana irigasi saluran tersier meningkat sebesar $2,37 \%$. 


\section{DAFTAR PUSTAKA}

Baja, Sumbangan. 2012. Tata Guna Lahan Dalam Pengembangan Wilayah. Yogyakarta: Andi Offset.

Fatah, Luthfi. 2006. Dinamika Pembangunan Pertanian dan Pedesaan. Banjarbaru Kalsel: Pustaka Buana.

Maulidah, Silvana. 2012. Modul Pelatihan: Sistem Agribisnis. Universitas Brawijaya: Malang.

Pemerintah Republik Indonesia. 2006. Peraturan Pemerintah Republik Indonesia Nomor 20 Tahun 2006 Tentang Irigasi. Jakarta.

Rencana Kebijakan Strategis Perluasan Areal Pertanian Baru Dalam Rangka Mendukung Prioritas Nasional Ketahanan Pangan. 2010. Badan Perencanaan Pembangunan Nasional: Jakarta.

Riyadi, Dodi Slamet. 2002. Pengembangan Wilayah dan Otonomi Daerah. Bab 3: Pengembangan Wilayah Teori dan Konsep. Jakarta: BPPT.

Singarimbun, Masri dan Sofian Efendi (Eds). 1995. Metode Penelitian Survei. Jakarta: LP3ES.

Situmorang, Lontung S. 2011. Tesis: Analisis Pengaruh Pembangunan Infrastruktur Terhadap Pertumbuhan Ekonomi Provinsi Sumatera Utara. Pascasarjana Ilmu Ekonomi, Universitas Negeri Medan: Medan.

Soenarno. 2003. Makalah: Pengembangan Kawasan Agropolitan Dalam Rangka Pengembangan Wilayah. Departemen Permukiman dan Prasarana Wilayah: Jakarta.

Syahza, Almasdi. 2005. Jurnal: Dampak Pembangunan Perkebunan Kelapa Sawit Terhadap Multiplier Effect Ekonomi Pedesaan di Daerah Riau. Universitas Negeri Riau: Riau.

Tukiyat. 2002. Pengembangan Wilayah dan Otonomi Daerah. Bab 6: Pengantar Pengembangan Ekonomi Wilayah. Jakarta: BPPT. 